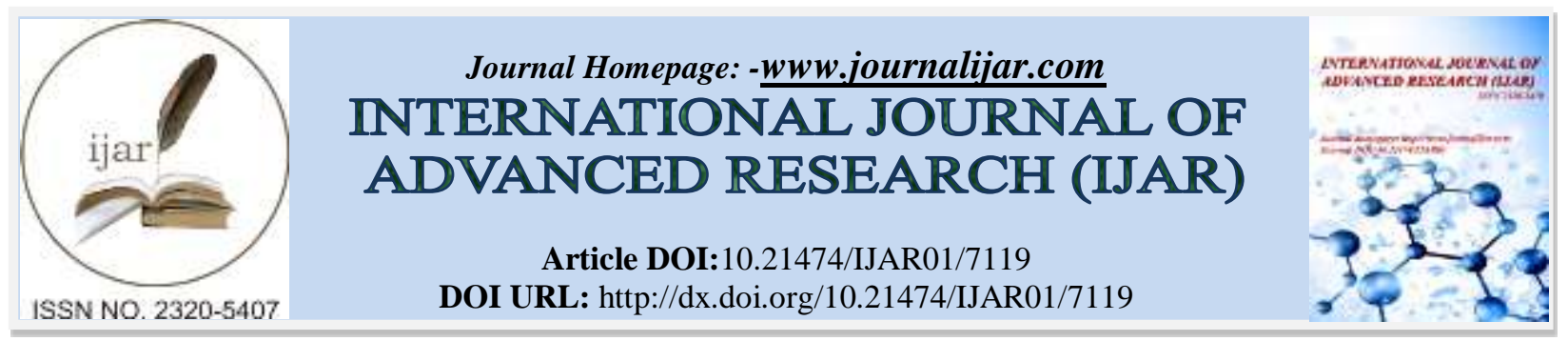

RESEARCH ARTICLE

\title{
A STUDY TO ASSESS THE KNOWLEDGE OF PREGNANT WOMEN REGARDING THE NUTRITIONAL NEEDS TO PREVENT ANEMIA DURING ANTENATAL PERIOD AT SELECTED HOSPITAL OF GURUGRAM, HARYANA.
}

\author{
Rebecca Dillu ${ }^{1}$ and Kusum Roy ${ }^{2}$. \\ 1. Assistant Professor, Department of Obstetrics and Gynaecological Nursing, Amity College of Nursing, Amity \\ University, Gurugram, Haryana, India. \\ 2. Tutor, Department of Medical and Surgical Nursing, Amity College of Nursing, Amity University, Gurugram, \\ Haryana, India.
}

\section{Manuscript Info}

\section{Manuscript History}

Received: 16 March 2018

Final Accepted: 18 April 2018

Published: May 2018

Keywords:-

Knowledge; nutritional needs to prevent anemia; pregnant women; antennal period.

\begin{abstract}
Aim: A study to assess the knowledge of pregnant women regarding the nutritional needs to prevent anemia during antenatal period at selected hospital of Gurugram, Haryana.

Methodology: Non Experimental descriptive survey design was adopted in the present study. Purposive sampling technique was used to select the sample size of 60 Pregnant women visiting the O.P.D for antenatal assessment at selected hospital of Gurugram. The pre-test assessment of knowledge of pregnant women was carried out using a structured knowledge questionnaire regarding the nutritional needs to prevent anemia during antenatal period.

Results: Assessment of the knowledge scores revealed that maximum (60\%) pregnant women were having average knowledge, less (23.3\%) were having poor knowledge while only few $(16.7 \%)$ were having good knowledge regarding iron deficiency anemia. Chi-square test was used to find the association between knowledge score with selected demographic variables. The results indicated that there was a significant association between the knowledge score and educational level of pregnant women, husband's education and personal habits. The knowledge score of pregnant women was assessed in seven different areas i.e. basic concept, nutritional needs, causes, sign and symptoms, diagnosis, prevention and complications of nutritional deficiency anaemia during antenatal period and it revealed that they were having lowest knowledge score in complication area and highest knowledge score in nutritional needs area.

Conclusion: The findings of the study depicts that most of the pregnant women had average knowledge, few had poor knowledge and very less pregnant women had good knowledge regarding nutritional needs of a pregnant women during pregnancy to prevent anemia.
\end{abstract}

Copy Right, IJAR, 2018,. All rights reserved. 


\section{Introduction:-}

\section{Background of the study}

Anemia in pregnancy is defined by World Health Organization (WHO) as a hemoglobin concentration below $11 \mathrm{gm} / \mathrm{dl} .{ }^{1}$ Iron-deficiency anemia is the most common form of malnutrition in the world and is the eighth leading cause of disease in girls and pregnant women in developing countries. Women's health is central to the survival of the society as they give beginning to the new life on the earth and cares for all the family members ${ }^{2}$.

The prevalence of anemia is very high i.e. (33-75\%) in developing countries to that of $15 \%$ in developed countries. According to National Family Health survey-III (2005-2006) prevalence of anemia among pregnant women in India is $58 \%$ which is higher as compare to the previous survey (NFHS - II).

Iron deficiency anemia is the most wide spread micronutrient deficiency during pregnancy affects one billion people worldwide and the United Nations Children's Fund's (UNICEF) emphasizes this global problem and goal to reduce the prevalence of anemia (including iron deficiency) to one third by $2010 .^{3}$

In India around $80 \%$ of pregnant women are anemic, $19 \%$ of maternal deaths are attributed to anemia. The prevalence was highest in Bihar (87.6\%) followed by Rajasthan (85.1\%) and Karnataka (82.7\%). ${ }^{4}$

\section{Need for the study:-}

Nutritional problems during pregnancy impact not only on women's quality of life, but consequently on her newborn's wellbeing after delivery, her family members and community as well. The nutritional status of the mother is the most important determinant of pregnancy outcomes, including the birth weight of the newborn. ${ }^{5}$

Anemia in pregnancy is one of the important public health problems. About $4-16 \%$ of maternal death is due to anaemia. It also increases the maternal morbidity, fetal and neonatal mortality and morbidity significantly. Therefore the investigator thought that Nutritional Anemia is the most frequent maternal complications during pregnancy, so antenatal care should be concerned with its early detection and management. ${ }^{6}$

\section{Statement Of The Problem:-}

A study to assess the knowledge of pregnant women regarding the nutritional needs to prevent anemia during antenatal period at selected hospital of Gurugram, Haryana with the following objectives:

1. To assess the knowledge of pregnant women regarding nutritional needs during antenatal period.

2. To find the association of knowledge score of pregnant women variables regarding the nutritional needs to prevent anemia during antenatal period with the selected demographic variables.

\section{Research Methodology:-}

A non experimental study using Survey approach and descriptive research design was conducted for 60 pregnant women visiting the O.P.D for antenatal assessment at ESIC Hospital, Gurugram, Haryana who were present at the time of study, could read and write Hindi and were willing to participate in the research study. Purposive sampling technique was used to select the sample for the research study.

A validated structured self administered questionnaire was developed to gather the demographic data and to assess the knowledge of the women regarding concept, nutritional needs, causes, sign and symptoms, diagnosis, prevention and complications related to nutritional deficiency anaemia. A validated structured questionnaire was used to assess the knowledge of the pregnant women regarding nutritional needs during antenatal period.

The reliability co-efficient for the structured knowledge questionnaire was calculated by using the Split half method. The reliability co-efficient was found to be 0.842 , thus the tool was found to be reliable.

Ethical approval was taken from the Medical Superintendent of the Hospital to conduct the study. Written informed consent was taken from the study sample regarding their willingness to participate in the research study and the purpose for carrying out research study was explained to the participants. Confidentiality of the information of the sample was maintained.

Data was analyzed by descriptive and inferential statistics i.e. frequency and percentage distribution, mean percentage, median of knowledge scores. 


\section{Result:-}

Frequency and percentage distribution of pregnant women according to their demographic data revealed that maximum( $42 \%$ ) pregnant women belongs to age 21-25years, (27\%) of age 26-30year, $20 \%$ were of age <20years \& very few (12\%) were of age more than 30years. More than half (57\%) pregnant women were multi gravida while less than half $(43 \%)$ were primi gravida. Most $(48 \%)$ of the pregnant women were living in nuclear family, less $(38 \%)$ in joint family and very few (13\%) were in living in extended family.

Thirty seven (37\%) pregnant women were educated till primary level, (28\%) were illiterate, less (15\%) were secondary educated, (13\%) were graduate \& above and very few (7\%) were senior secondary educated. More than half $(53 \%)$ pregnant women were house maker, $(22 \%)$ were self-employed,(13\%) were private employee and very few $(12 \%)$ were government employee. maximum $(55 \%)$ pregnant women were Hindu, $(23 \%)$ were Muslim, $(12 \%)$ were Christian, (10\%) were Sikh and none was belong to others. shows maximum (45\%) pregnant women belonged to monthly income of Rs.5000-10,000 , less (22\%) belonged to monthly income of Rs. $<5000$,very less (18\%) belonged to monthly income of Rs.15000-20000 \& very few (15\%) were belongs to $>20000$.

Maximum (30\%) pregnant women get knowledge from self study, (27\%) from health care centre, (22\%) from relatives and friends \& mass media each. maximum (57\%) pregnant women were living in urban area and (43\%) in rural area. The data depicts that most $(40 \%)$ of the pregnant women were non vegetarian, other $(33 \%)$ were vegetarian and very few (10\%) take all kind of food. Most of the husbands (43\%) of pregnant women were primary school, other $(42 \%)$ were illiterate, very less $(10 \%)$ were graduate and above \& very few $(5 \%)$ were educated till secondary school.

More than half $(55 \%)$ pregnant women got married at the age of $<20$, less than half $(43 \%)$ married at age of 21 25years, $(2 \%)$ at age of 26-30years and none was get married at the age $>30$. The data also shows that maximum (72\%) pregnant women were in first trimester, $(23 \%)$ in second trimester and very few $(5 \%)$ in $3^{\text {rd }}$ trimester. Maximum (77\%) pregnant women had no bad habits, other (22\%) had habit of smoking while very few (2\%) had habit of taking alcohol and none of them were drug addict.

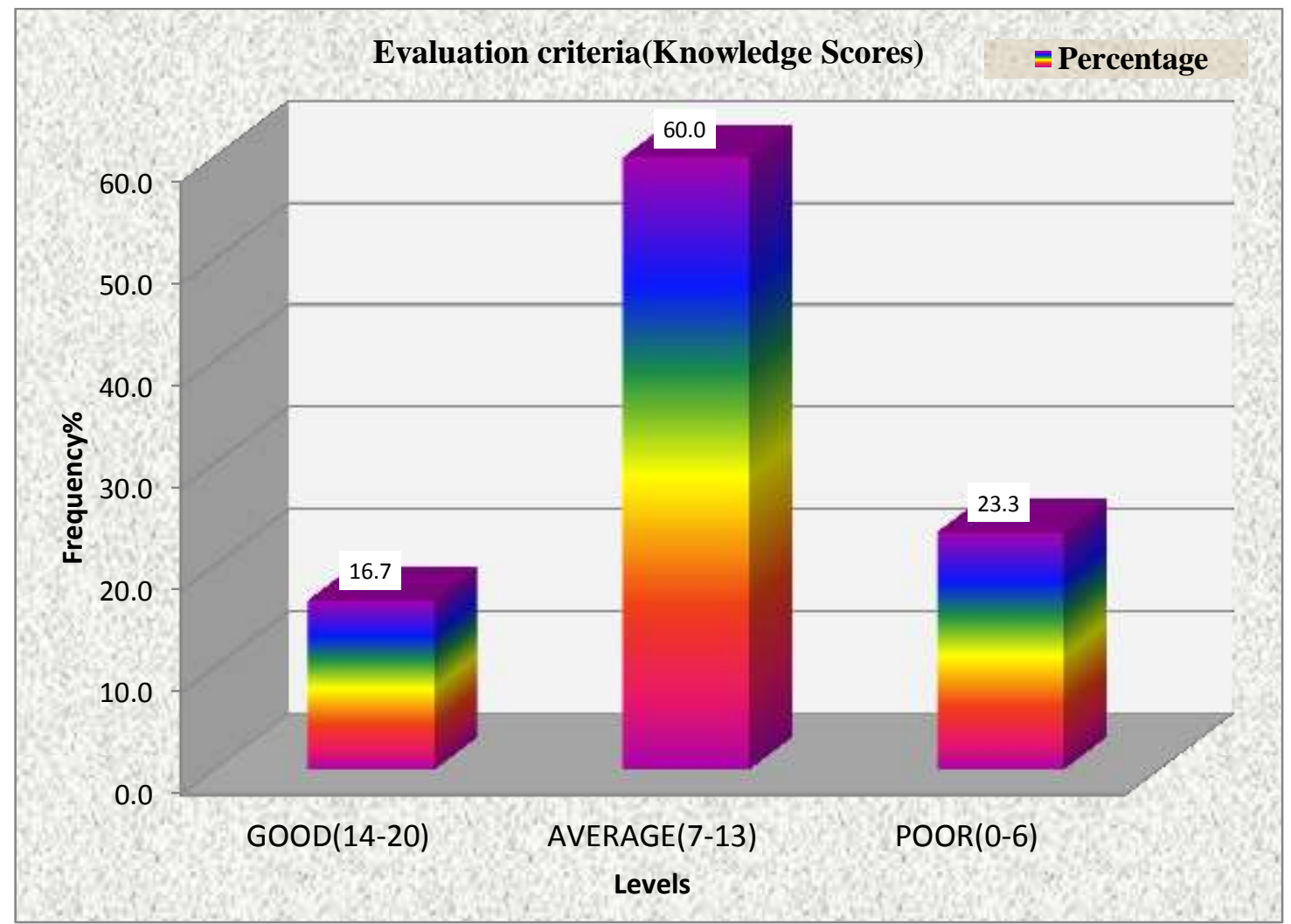

Figure 1:-Frequency and Percentage Distribution of Pregnant Women Based on Knowledge Scores Categories 
Table 1:-Mean, Median, Standard Deviation \& Mean percentage of Knowledge Scores of Pregnant Women N=60

\begin{tabular}{|c|c|c|c|c|c|}
\hline Descriptive Statistics & Range & Mean & SD & Median & Mean \% \\
\hline Knowledge Score & $2-16$ & 9.43 & 3.65 & 9.00 & 47.2 \\
\hline
\end{tabular}

\section{Maximum score $=20$ Minimum score $=0$}

Table 1 depicts that overall knowledge score of pregnant women was in the Range between 2-16, mean \pm SD (9.43 $\pm 3.65)$ \& mean percentage came out to be 47.2 .

Table 2:-Area wise Mean, Median, Standard Deviation \& Mean percentage of Knowledge Scores of Pregnant Women

\begin{tabular}{|l|l|l|l|l|}
\hline Areas & Range & Mean \pm Sd & Mean \% & Rank \\
\hline Basic Concept & $0-4$ & $2.07 \pm 1.30$ & 51.7 & II \\
\hline Nutritional Needs & $1-6$ & $3.27 \pm 1.66$ & 54.4 & I \\
\hline Causes & $0-2$ & $0.98 \pm 0.79$ & 49.2 & III \\
\hline Sign \& Symptoms & $0-1$ & $0.42 \pm 0.50$ & 41.7 & IV \\
\hline & & & & \\
\hline Diagnosis & $0-1$ & $0.38 \pm 0.49$ & 38.3 & VI \\
\hline Prevention & $0-5$ & $2.03 \pm 1.25$ & 40.7 & V \\
\hline Complications & $0-1$ & $0.28 \pm 0.45$ & 28.3 & VII \\
\hline
\end{tabular}

Maximum score $=20$ Minimum score $=0$

Table 2 depicts that knowledge score of pregnant women was assessed in seven different areas i.e. basic concept, nutritional needs, causes, sign and symptoms, diagnosis, prevention and complications of nutritional deficiency anaemia during antenatal period.

Table 3:-Association of Knowledge Score of Pregnant Women with the Selected Demographic Variables Using Chi Square

\begin{tabular}{|c|c|c|c|c|c|c|c|c|c|}
\hline \multicolumn{2}{|c|}{ Demographic Variables } & \multicolumn{3}{|c|}{ Levels(N=60) } & \multicolumn{5}{|c|}{ Association with KNOWLEDGE Score } \\
\hline Variable & Opts & GOOD & AVERAGE & POOR & $\begin{array}{l}\text { Chi } \\
\text { Test }\end{array}$ & $\begin{array}{c}\mathbf{P} \\
\text { Value }\end{array}$ & df & $\begin{array}{l}\text { Table } \\
\text { Value }\end{array}$ & Result \\
\hline \multirow[t]{4}{*}{ Age in years } & $<20 \mathrm{yr}$ & 1 & 5 & 6 & \multirow[t]{4}{*}{6.949} & \multirow[t]{4}{*}{0.326} & \multirow[t]{4}{*}{6} & \multirow[t]{4}{*}{12.592} & \multirow{4}{*}{$\begin{array}{c}\text { Not } \\
\text { Significant }\end{array}$} \\
\hline & $21-25 y r$ & 4 & 17 & 4 & & & & & \\
\hline & $26-30 \mathrm{yr}$ & 4 & 9 & 3 & & & & & \\
\hline & $>30 \mathrm{yr}$ & 1 & 5 & 1 & & & & & \\
\hline \multirow[t]{2}{*}{ Gravida } & $\begin{array}{l}\text { Primi } \\
\text { Gravida }\end{array}$ & 3 & 15 & 8 & \multirow[t]{2}{*}{1.852} & \multirow[t]{2}{*}{0.396} & \multirow[t]{2}{*}{2} & \multirow[t]{2}{*}{5.991} & \multirow[t]{2}{*}{$\begin{array}{c}\text { Not } \\
\text { Significant }\end{array}$} \\
\hline & $\begin{array}{l}\text { Multi } \\
\text { Gravida }\end{array}$ & 7 & 21 & 6 & & & & & \\
\hline \multirow{3}{*}{$\begin{array}{l}\text { Type of } \\
\text { Family }\end{array}$} & Nuclear & 4 & 19 & 6 & \multirow[t]{3}{*}{5.901} & \multirow[t]{3}{*}{0.207} & \multirow[t]{3}{*}{4} & \multirow[t]{3}{*}{9.488} & \multirow{3}{*}{$\begin{array}{c}\text { Not } \\
\text { Significant }\end{array}$} \\
\hline & Joint & 6 & 13 & 4 & & & & & \\
\hline & Extended & 0 & 4 & 4 & & & & & \\
\hline \multirow[t]{5}{*}{ Educational } & Illiterate & 0 & 7 & 10 & \multirow[t]{5}{*}{68.343} & \multirow[t]{5}{*}{0.000} & \multirow[t]{5}{*}{8} & \multirow[t]{5}{*}{15.507} & \multirow[t]{5}{*}{ Significant } \\
\hline & $\begin{array}{l}\text { Primary } \\
\text { School }\end{array}$ & 0 & 18 & 4 & & & & & \\
\hline & $\begin{array}{l}\text { Secondary } \\
\text { School }\end{array}$ & 0 & 9 & 0 & & & & & \\
\hline & $\begin{array}{l}\text { Senior } \\
\text { Secondary }\end{array}$ & 2 & 2 & 0 & & & & & \\
\hline & $\begin{array}{l}\text { Graduate } \\
\text { and Above }\end{array}$ & 8 & 0 & 0 & & & & & \\
\hline \multirow[t]{2}{*}{ Occupation } & $\begin{array}{l}\text { House } \\
\text { Maker }\end{array}$ & 3 & 21 & 8 & \multirow[t]{2}{*}{5.844} & \multirow[t]{2}{*}{0.441} & \multirow[t]{2}{*}{6} & \multirow[t]{2}{*}{12.592} & \multirow[t]{2}{*}{$\begin{array}{c}\text { Not } \\
\text { Significant }\end{array}$} \\
\hline & $\begin{array}{l}\text { Government } \\
\text { Employee }\end{array}$ & 3 & 3 & 1 & & & & & \\
\hline
\end{tabular}




\begin{tabular}{|c|c|c|c|c|c|c|c|c|c|}
\hline & $\begin{array}{l}\text { Private } \\
\text { Employee }\end{array}$ & 2 & 5 & 1 & & & & & \\
\hline & $\begin{array}{l}\text { Self } \\
\text { Employed }\end{array}$ & 2 & 7 & 4 & & & & & \\
\hline \multirow[t]{5}{*}{ Religion } & Hindu & 6 & 19 & 8 & \multirow[t]{5}{*}{2.695} & \multirow[t]{5}{*}{0.846} & \multirow[t]{5}{*}{6} & \multirow[t]{5}{*}{12.592} & \multirow{5}{*}{$\begin{array}{c}\text { Not } \\
\text { Significant }\end{array}$} \\
\hline & Muslim & 1 & 9 & 4 & & & & & \\
\hline & Christian & 1 & 5 & 1 & & & & & \\
\hline & Sikh & 2 & 3 & 1 & & & & & \\
\hline & Others & 0 & 0 & 0 & & & & & \\
\hline \multirow{4}{*}{$\begin{array}{l}\text { Monthly } \\
\text { Family } \\
\text { Income: (in } \\
\text { rupees) }\end{array}$} & $<5000$ & 2 & 10 & 1 & \multirow[t]{4}{*}{11.794} & \multirow[t]{4}{*}{0.067} & \multirow[t]{4}{*}{6} & \multirow[t]{4}{*}{12.592} & \multirow{4}{*}{$\begin{array}{c}\text { Not } \\
\text { Significant }\end{array}$} \\
\hline & $5000-10000$ & 4 & 16 & 7 & & & & & \\
\hline & $\begin{array}{l}15000- \\
20000\end{array}$ & 1 & 4 & 6 & & & & & \\
\hline & $>20000$ & 3 & 6 & 0 & & & & & \\
\hline \multirow{4}{*}{$\begin{array}{l}\text { Source of } \\
\text { Information }\end{array}$} & Self Study & 4 & 11 & 3 & \multirow[t]{4}{*}{6.917} & \multirow[t]{4}{*}{0.329} & \multirow[t]{4}{*}{6} & \multirow[t]{4}{*}{12.592} & \multirow{4}{*}{$\begin{array}{c}\text { Not } \\
\text { Significant }\end{array}$} \\
\hline & Mass Media & 0 & 9 & 4 & & & & & \\
\hline & $\begin{array}{l}\text { Relatives } \\
\text { and Friends }\end{array}$ & 1 & 9 & 3 & & & & & \\
\hline & $\begin{array}{l}\text { Health care } \\
\text { Centre }\end{array}$ & 5 & 7 & 4 & & & & & \\
\hline \multirow{2}{*}{$\begin{array}{l}\text { Place of } \\
\text { Residence }\end{array}$} & Urban & 7 & 21 & 6 & \multirow[t]{2}{*}{1.852} & \multirow[t]{2}{*}{0.396} & \multirow[t]{2}{*}{2} & \multirow[t]{2}{*}{5.991} & \multirow{2}{*}{$\begin{array}{c}\text { Not } \\
\text { Significant }\end{array}$} \\
\hline & Rural & 3 & 15 & 8 & & & & & \\
\hline \multirow{4}{*}{$\begin{array}{l}\text { Dietary } \\
\text { Pattern }\end{array}$} & Vegetarian & 3 & 12 & 5 & \multirow[t]{4}{*}{4.861} & 0.562 & 6 & 12.592 & Not \\
\hline & $\begin{array}{l}\text { Non } \\
\text { Vegetarian }\end{array}$ & 5 & 15 & 4 & & & & & Significant \\
\hline & Eggetarian & 0 & 6 & 4 & & & & & \\
\hline & $\begin{array}{l}\text { All of } \\
\text { Above }\end{array}$ & 2 & 3 & 1 & & & & & \\
\hline Husband & Illiterate & 4 & 18 & 3 & 12.745 & 0.047 & 6 & 12.592 & Significant \\
\hline Education & $\begin{array}{l}\text { Primary } \\
\text { School }\end{array}$ & 3 & 14 & 9 & & & & & \\
\hline & $\begin{array}{l}\text { Secondary } \\
\text { School }\end{array}$ & 0 & 1 & 2 & & & & & \\
\hline & $\begin{array}{l}\text { Graduate } \\
\text { and Above }\end{array}$ & 3 & 3 & 0 & & & & & \\
\hline Age at the & $<20$ & 4 & 19 & 10 & 6.731 & 0.151 & 4 & 9.488 & Not \\
\hline time of & $21-25$ & 6 & 17 & 3 & & & & & Significant \\
\hline Marriage & $26-30$ & 0 & 0 & 1 & & & & & \\
\hline & $>30$ & 0 & 0 & 0 & & & & & \\
\hline $\begin{array}{l}\text { Antenatal } \\
\text { Registration }\end{array}$ & $\begin{array}{l}\text { 1st } \\
\text { Trimester }\end{array}$ & 9 & 25 & 9 & 5.118 & 0.275 & 4 & 9.488 & $\begin{array}{c}\text { Not } \\
\text { Significant }\end{array}$ \\
\hline done during & $\begin{array}{l}\text { 2nd } \\
\text { Trimester }\end{array}$ & 0 & 9 & 5 & & & & & \\
\hline & $\begin{array}{l}\text { 3rd } \\
\text { Trimester }\end{array}$ & 1 & 2 & 0 & & & & & \\
\hline Personal & Smoking & 0 & 5 & 8 & 14.977 & 0.005 & 4 & 9.488 & Significant \\
\hline Habits & Alcoholism & 0 & 1 & 0 & & & & & \\
\hline & Drugs & 0 & 0 & 0 & & & & & \\
\hline & $\begin{array}{l}\text { None of the } \\
\text { Above }\end{array}$ & 10 & 30 & 6 & & & & & \\
\hline
\end{tabular}

Data in Table 3 depicts that Chi-square test was used to find the association between knowledge score with selected demographic variables. The results indicated that there was a significant association between the knowledge score and educational level of pregnant women, husband's education and personal habits. 


\section{Discussion:-}

The present study shows that the majority (60\%) of the pregnant women were having average knowledge which was similar to the findings of the study conducted by Baby A, Venugopal J, D'silva $\mathbf{R}$ et al. (2014) conducted a Nonexperimental descriptive study to determine the knowledge of 50 antenatal mothers regarding management of anemia during pregnancy from which showed that the majority of the antenatal mothers $(54 \%)$ had satisfactory knowledge, $38 \%$ had poor knowledge, and $8 \%$ had good knowledge regarding anemia during pregnancy. The study concluded that pregnant women had average knowledge.

\section{Conclusion:-}

On the basis of findings of the present study, the following conclusion can be drawn:

The study illuminates that very less women were educated and most of pregnant women get married in early age therefore the findings of the study depicts that most of the pregnant women had average knowledge, few had poor knowledge and very less pregnant women had good knowledge regarding nutritional needs of a pregnant women during pregnancy to prevent anemia. The study indicated that the pregnant women were lacking knowledge in different areas of nutritional deficiency anemia that can lead to various complications for women as well as their babies i.e. abortion, maternal mortality, IUGR, preterm baby etc. Hence the nurses must increase their efforts to impart more knowledge and create awareness on treatment to prevent anaemia in pregnancy. There should be mandatory preconception and antenatal counselling sessions for the women to identify the risk factors in pregnancy and structured teachings to reduce the enormous burden of anaemia in pregnancy.

\section{References:-}

1. World Health Organization (WHO). The prevalence of Anemia in women: a tabulation of available information. Geneva, Switzerland: WHO; 1992.

2. Wright.D. Anemia in pregnancy. http://www.articlesbase.com/womens-health-articles/anemia-in-pregnancy1541442.html.Dec 4, 2009.

3. United Nations International Children Education Fund, World Food Programme, Ministry of Health and Non Governmental Organization partners. The State of the world's children: Literature review on maternal anaemia and iron supplementation.Islamabad. : Ministry of Health and Non Governmental Organizations, 2000.

4. K Park. Text book of Preventive \& Social Medicine. India, Banarsidas Bhanot publications.2013. Pp- 595.

5. Dharma lingam A, Navanetham K, Krishna Kumar CS. Nutritional status of mothers and low birth weight in India. Maternal Child Health J. 2010; 14: 290-98.

6. Gopalan C. Nutritional research in South East Asia. $1^{\text {st }}$ ed. Delhi; ATB Publishers; 1996; P-42-44. 